\title{
ULUSAL PROGRAMDA VE İLERLEME RAPORLARINDA EĞİTIM
}

\section{Murat Gürkan GÜLCAN*}

\section{$\ddot{O} z e t:$}

Avrupa Birliği tarafindan eğitim ve kültür yakın zamana kadar her ülkede, hatta bazl Avrupa ülkelerinde her eyalet ve toplulukta serbest bir alan olarak görülmekteydi. Avrupa Birliği'nin bir siyasal birliğe doğru gelişmesine paralel olarak "ortak değerler" öne çıkmaya başlamış;..buna bağlı olarak "ortak yaşam alanı Avrupa", "tek bir Avrupa için eğitim", veya "Avrupa yurttaşlığl" gibi sloganlar belgelere yansımaya başlamıştır. Türkiye 'nin Ulusal Program hedeflerini ne düzeyde gerçekleştirdiği Avrupa Komisyonu tarafindan her yılın sonunda yayimlanan Ilerleme Raporları'nda belirtilmektedir. Raporlarda eğitim konusunda da henüz tamamlanması gereken pek çok konu yer almaktadır. Bunların tamamlanması Türkiye'nin adaylık sürecine önemli bir katkı sağlayacaktır.

Anahtar Sözcükler: Ulusal Program, AB ve eğitim, ilerleme raporlarl, eğitim ve kültür.

\section{Abstract:}

The European Union until recently perceived education and culture as free policy areas in every country, even in every and each state and community in some European countries. "Common values" have emerged in parallel with the development of the European Union into a political union. Thus, slogans as "Europe, the common living area", "Education for the whole Europe", or "European Citizenship" have appeared in documents. Achievements of Turkey on the National Program objectives are stated in the Progress Reports prepared by the European Commission at the end of every year. In these reports, there are also many inadequacies in education that still be accomplished. These achievements will make great contributions to the accession process of Turkey to the European Union.

\footnotetext{
“Yrd. Doç. Dr., Gazi Üniversitesi, Teknik Eğitim Fakültesi, Eğitim Bölümü Öğretim Üyesi
} 
Key Words: National Program, the EU and education, Progress Reports, education and culture.

\section{Giriș}

Türkiye Cumhuriyeti Devleti'nin Avrupa Birliği ile ilişkileri 50 yıllık bir geçmişe dayanmaktadır. Türkiye, Avrupa Ekonomik Topluluğunun 1958 yılında kurulmasından kısa bir süre sonra Temmuz 1959'da Topluluğa tam üye olmak için başvurmuştur. Cumhuriyetimizin kurulmasından bu yana, hatta Cumhuriyet öncesinden başlayan çağdaşlaşma hareketi, ülkemizi özellikle ikinci Dünya Savaşından sonra Avrupa merkezli bütün oluşumlara katılmaya yöneltmiştir. Böylece Türkiye, Avrupa Konseyi, OECD ve NATO'ya girmiş ve 20. yüzyılın en iddialı oluşumu olan Avrupa Birliği'ne aday olmuştur.

Türkiye'nin AB'ye adaylık sürecini başlatan 10-11 Aralık 1999 Helsinki Zirvesi'ndeki ortaklık koşullarına dayanılarak 2000 yılı sonunda bir Ulusal Program hazırlanmış ve AB'ye sunulmuştur. Haziran 1998'de yapılan Cardiff AB Konseyi toplantısında, yeni aday ülkelerin katılım sürecinde kaydettiği ilerlemeleri 1998 yılından itibaren sunması Komisyon tarafindan benimsenmiştir. Türkiye'nin topluluğa katılım yönünde ilerlemesine ilişkin ilk düzenli rapor 1998 yılında sunulmuştur; 2000 yılından itibaren sunulan raporlar ise ilerleme raporları olarak adlandırılmıştır.

14-15 Aralık 2001 tarihlerinde Brüksel / Laeken'de gerçekleştirilen AB Laeken Devlet ve Hükümet Başkanları Zirvesi Türkiye-AB ilişkileri açısından olumlu geçmiş ve üyelik yolunda önemli kazanımlar sağlamıştır. Sonuç Bildirgesinin 12. paragrafinda Türkiye ile tam üyelik müzakerelerinin açılmasına yer verilmiştir. Raporda AB'nin geleceği konusunda oluşturulan Konvansiyon'a Türkiye'nin de diğer adaylarla eşit statüde katılmasına yer vermiştir.

17 Aralık 2004'te Brüksel'de toplanan AB Parlamentosu Türkiye'ye tam üyelik için müzakerelere başlama kararını verilmiştir. Avrupa Birliği'nin genişlemesi kapsamında diğer aday ülkelerden farklı olarak Türkiye'ye 2014 ten önce tam üyeliğin gerçekleşemeyeceği bir müzakere süreci verilmiş, müzakerelerin başlaması için 3 Ekim 2005 tarihi belirlenmiştir. 3 Ekim 2005'te Lüksemburg'da Türkiye'nin AB üyelik müzakereleri çerçeve belgesi imzalanmış ve 20 Ekim 2005 tarihinden itibaren tarama süreci başlatılmıştır.

35 başlıktan oluşan tarama sürecinde 26. başlık olarak belirlenmiş bulunan 'Eğitim ve Kültür' konusundaki tarama sürecine 26 Ekim 2005 tarihinde Brüksel'de yapılan bir tanıtıcı tarama toplantısı ile başlanmıştır. 
Eğitim ve Kültür başlığındaki ikinci tarama toplantısı ise 16 Kasım 2005 tarihinde yapılmıștır. 25 Ekim 2005 tarihinde AB Eğitim ve Kültür Genel Müdürlüğü ile $\mathrm{AB}$ Türkiye daimi Temsilciliği arasında 'Kültür 2000' Programına katılım konusunda mutabakat zaptı imzalanmıştır.

Eğitimde iş birliği Avrupa'nın olduğu kadar Dünya'nın gündemini de sık sık meşgul etmekte, eğitim ve kültür konularında özgünlüğün korunarak ortak değerler oluşturulması giderek önem kazanmaktadır. Eğitim ve kültür, yakın zamana kadar her ülkenin, hatta bazı Avrupa ülkelerinde her eyaletin ve topluluğun değerlerine sadık kalarak geliştirdiği iki alan olarak görülmektedir. Son yıllarda Avrupa Birliği'nin bir siyasal birliğe doğru gelişmesine paralel olarak 'ortak değerler' den söz edildiği gözlemlenmektedir. Avrupa Birliği organlarında 'ortak yaşam alanı Avrupa', 'tek bir Avrupa için eğitim' veya 'Avrupa yurttaşlığı' gibi sloganlar son yillarda daha çok duyulmakta ve belgelere de yansitılmaktadır.

Avrupa'nın ortak değerleri ve Türkiye'nin Avrupa Birliği adaylığı pek çok konuda olduğu gibi eğitim konusunda da oldukça uzun bir yol olarak görülmektedir. Bu kapsamda yapısal değişikler başta olmak üzere örgün ve yaygın eğitimde disiplin alanları ve disiplinler arası ilişkiler, denklikler ve tanıma, öğretim programlarında içerik, yöntem ve teknikler ile öğretim materyallerinin yeniden hazırlanması kanımca sadece bir başlangıç sayllabilir. Diğer taraftan $\mathrm{AB}$ eğitim programlarından genel eğitim Socrates, mesleki eğitim Leonardo da Vinci ve Avrupa için Gençlik programlarına katılma ve mesleki eğitimde ortak standartlar ve tanımlar $A B$ 'ne uyumda eğitim alnında uzun ve yorucu çalışmalar gerektirmektedir. Ayrica başta öğretmen olmak üzere öğretim sürecindeki aktörlerin (öğretmen, veli, öğrenci, danışman, yönetici, denetici, vb.) rolleri yeniden tanımlanacak, öğretmen yeterliklerinin alana yansıması ise uzun bir zaman alacak bir süreç olarak karşımıza çıkmaktadır.

Avrupa Birliği'ne adaylık sürecinde Ulusal Program ve İlerleme Raporlarında eğitimin durumunu anlayabilmek için öncelikle Avrupa Birliği'nin eğitim politikalarını anlamakta yarar vardır.

\section{Avrupa Birliği'nin Eğitim Politikası}

Avrupa Birliği'ne üye ülkelerin eğitim sistemlerinde önemli farklılıklar bulunmaktadır. Bunun nedeni farklı kültürel ve çeşitli tarihsel değerlerdir. 
1976'da AB Komisyonu, eğitim faaliyetlerinin temsilcilerden oluşacak bir kurul tarafindan yürütülmesine karar vermiş ve $A B$ Eğitim Komisyonu kurulmuştur. Komisyon eğitim politikalarını şu başlıklar altında toplamıştır (Milli Ĕgitim Politikaları ve Şuralar,1996:36):

1. Göçmen işçiler ve bunların aile bireylerinin eğitim ve öğretimi,

2. Eğitim sistemleri arasında yakınlaşma sağlanması,

3. Birlik düzeyinde belge ve istatistiklerin yayınlanması,

4. Yabancı dil öğretiminde niteliğin artırılması,

5. Öğretmen, öğrenci ve araştırmacılara daha özgür bir çalışma ortamı sağlanması,

6. Üye ülkelerdeki eğitim kurumlarına girişlerde firsat eşitliğinin sağlanması.

$\mathrm{Bu}$ programa ek olarak; gençlerin mesleki eğitimlerinin desteklenmesi, okuldan meslek yaşamına geçişlerin düzenlenmesi, gençliğin istihdamı, önlemlerin alınması maddeleri eklenmiştir (Milli Eğitim Politikaları ve Şuralar, 1996:36).

AB Eğitim politikası şu başlıklar altında uygulamaya konmuştur:

1. Öğretmen ve Öğrenci Değişimi: Üye ve aday ülkeler arasında karş1lıklı deneyim paylaşımı.

2. Birlik Mevzuatında Eğitim: Avrupa Araştırma Enstitülerinin kurulmasını ve Avrupa Dokümantasyon Merkezlerinin oluşturulması.

3. Yabancı Dil Öğretimi: Avrupa dillerinin öğrenilmesi,

- Ana dili dışında iki yabancı dilin öğrencilere kazandırılması,

- Yabancı dil öğretmenlerinin öğrettikleri dilin ülkesini ziyaret etmesi,

4. Okul Hayatından İş Hayatına Geçiş: (14-18 yaş) İşsizliği azaltmak. 13 milyon işsizin \% 40'1 25 yaşın altında.

5. Eğitimde Fursat Eşitliği:

a) Kadın Okur-yazarlı̆g 1

b) Göçmenler: Birlik, işçilerin üye ülkeler arasındaki serbest dolaşımları.

c) Özürlüler:

d) Okumaz-yazmazlık:

6. Yeni Bilgi Teknolojisi:

a) Her Yeni Yıl Yaklaşırken Eğitim ve Öğretim:

b) Eğitimde fırsat eşitliğini yaygınlaştırmak, sürekliliği sağlanarak eğitimin niteliğini yükseltmek,

c) Üye ülkelerin bilgi ve deneyimlerinden yararlanarak eğitim sistemlerini geliştirmek,

d) Üye ülkelerde ortak demokratik değerler geliştirmek, 
e) Topluluğun çok kültürlü özelliğini anlamak,

f) Bireylerin/topluluk ölçeğinde Avrupalılık bilincini oluşturmak.

Maastricht Anlaşmasına Göre Eğitim: Maastricht Antlaşması'nın 126. maddesine göre;

- Özellikle üye devletlerin dillerini yayma ve öğretme

- Diplomalarının tanınmasi.

- Bilgi ve deneyim alışverişi,

- Gençlerin değişimini özendirmek,

- Uzaktan eğitimi geliştirmek; hedeflenmektedir.

Sonuç olarak Avrupa Birliğinin eğitim politikası en genel anlamda şu temel ilkelere dayandırılmaktadır (Milli Eğitim Politikaları ve Şuralar, 1996:39):

- Tek bir Avrupa için eğitim,

- Öğrenen toplum,

- Yüksek kalitede eğitim,

- Sürekli eğitim,

- Eğitimde firsat eșitliği,

- Eğitimde ve mesleki yöneltmede işbirliği,

- Karşılıklı deneyim paylaşımı,

- Örgün eğitimde, açıklık ve işbirlikçi yöntemlerinin desteklenmesi,

- İnteraktif öğretim yöntemlerin geliştirilmesi.

- Okullarda öz değerlendirmeye dayalı yöntemin özendirilmesi,

- Sürekli eğitim.

\section{Avrupa Birliği Eğitim Projeleri}

Avrupa Birliği'nin eğitimle ilgili üç programı vardır. Bu programlar aynı zamanda proje olarak uygulanmaktadır. Bu programlara ülkemiz 2004 yılından itibaren katılmaktadır. Bu projelere aşağıda yer verilmiştir.

\section{1. Sokrates}

Sokrates, eğitimde işbirliği amaçlı Avrupa Birliği eylem programıdır. Bu program, yükseköğretim, örgün eğitim ve dil öğrenimi olmak üzere üç alanı kapsamaktadır. Avrupa'da her yaş ve düzeyindeki eğitimi kapsayan ilk girişimdir.

Sokrates programının amaçları şunlardır:

- AB üyeleri arasında bir kültür alışverişi yaparak, bütün alanlarda Avrupa boyutunu geliştirmek 
- Üye ülkelerin, dilleri ve yaşam koşulları hakkında bilgi sahibi olmak

- Öğretim üyesi ve üniversite personeli ile üniversite öğrencilerine, çalışmalarını diğer üye ülkelerde tamamlama fırsatı vermek. Bu şekilde, Avrupa çapında bir bilgi ağı oluşturmak.

Sokrates programının yürütülmesinden, Avrupa Komisyonu sorumludur. Sokrates Programının uygulanmasında Türkiye ortaklığı sözleşmesi 27 Aralık 2002 tarihinde Türkiye ve Avrupa Birliği Komisyonu tarafindan imzalanmış ve 2004 yılından itibaren programa katlım başlamıştır.

\section{2. Leonardo da Vinci}

Leonrado da Vinci, Avrupa Birliği'nin Mesleki Eğitim Politikasını belirlemeyi amaçlayan bir eğitim programıdır.

Bu program da iki dönemden oluşmaktadır. Birinci aşaması l Ocak 1995 yılında başlamıştır ve bu 31 Aralık 1999 tarihine kadar uygulanmıştır. Programın, ikinci dönemi 2000-2006 tarihleri arasını kapsar. Avrupa Parlamentosu Genel Kurul Kararı ile 28 Ekim 1999'da Türkiye de bu programa dahil edilmiştir.

Teknik yardım ve işbirliği, bu programdaki temel amaçtır. Bu kapsamda, pilot projelerin uygulanması, uluslar arası hareketliliğin sağlanması, dil becerilerinin geliştirilmesi, uluslar arası iletişim ağlarının kurulması, referans malzemelerinin hazırlanması ve ortak eylemler yapılmasi hedeflenmiştir (Milli Eğitim Politikaları ve Şuralar, 1996:40).

\section{3. Avrupa Gençliği Programı}

14 Mart 1995 yılından başlayarak 5 yıllık bir dönemi kapsayan programa, AB ülkeleri yanında, Liechtenstein, Norveç, Çek Cumhuriyeti, Macaristan, Romanya, Polonya, Slovak Cumhuriyeti, Estonya, Letonya, Litvanya ve Güney Kıbrıs Rum Yönetimi de katılmaktadır. Programın ikinci aşamasında Türkiye de programa katılmıştır.

Avrupa Gençliği Programı, 15-25 yaş arasındaki gençler için tasarlanmıştır. Programın içeriğinde, üçüncü ülkelerle değişimler (AB üyesi dışındaki devletlere kapalıdır), genç iş̧iler, gençleri ilgilendiren faaliyetler, gençlere yönelik araştırmalar ve bilgiler vardır.

Program, gençlerin sahip oldukları kültürel ve sosyal çevreyle AB'nin bir parçasını oluşturduklarının farkına varmalarını, farklı ırktan ve etnik kökenden olan insanlara saygı duymayı öğretme ve dışlama, ırkçılık, 
yabancı düşmanlığı gibi kavramların zararlarını vurgulamayı, kadın erkek eşitliğinin algılanmasının gerekliliğinin anlatılmasını amaçlar.

Ayrıca, gençlerin düşüncelerini özgürce açıklamalarını, sosyal, kültürel ve çevresel düzeylerde, bağımsızlık, yaratıcılık ve girişimcilik ruhunun geliştirilmesini sağlamak, programın bir başka amacıdır (Milli Eğitim Politikaları ve Şuralar, 1996:40).

\section{Türkiye Ulusal Programı'nda Eğitim}

Türkiye'nin AB'ye adaylık sürecini başlatan 10-11 Aralık Helsinki Zirvesi'ndeki ortaklık koşullarına dayanılarak 2000 yılı sonunda bir Ulusal Program hazırlanmış ve AB'ye sunulmuştur. Program, hayatın hemen her alanında 33 başlık (daha sonra bu başlık sayısı 35'e çıkarılmıştır) ve 110 alt başlıkta Türkiye'nin kısa, orta ve uzun vadeli planlarını içermektedir (Gülcan, 2005-57). Ulusal Programda yer alan bölümlerden biri de Eğitim, Staj ve Gençlik olarak belirtilmektedir. Bu bölümde Ulusal Programda eğitim konusuna yer veren Eğitim Staj ve Gençlik adlı 4.19. Bölüme aşağıda kısaca yer verilmiştir.

İlköğretim ve ortaöğretim düzeyinde okullaşma oranları $\mathrm{AB}$ ülkelerinde ortalama yüzde 100'e ulaşmış olduğu halde, bu oran 1999-2000 öğretim yılı itibarıyla ülkemizde ilköğretimde yüzde 97,6 , ortaöğretimde ise yüzde 59,4'tür. Yükseköğretimdeki okullaşma oranı, AB ülkelerinde ortalama yüzde 43 iken bu oran ülkemiz için yüzde 29 düzeyindedir. Toplumun eğitim düzeyinin yükseltilmesi amacıyla 1997 yılında çıkarılan 4306 sayılı Yasa ile zorunlu ilköğretimin süresi beş yıldan sekiz yıla çıkarılarak ilköğretimdeki okullaşma oranında önemli bir artış sağlanmıştır. 8 İNCí. Beş Yıllık Kalkınma Planı dönemi sonunda ilköğretimde okullaşma oranı yüzde 100 olarak hedeflenmiştir.

Ülkemizde genel bütçeden eğitime ayrılan payın düşüklüğüne vurgu yapılarak; toplam eğitim harcamalarının GSMH'ya oranı AB ülkeleri için ortalama $\% 5$, OECD ülkeleri için ise ortalama $\% 6$ düzeyinde olduğu, buna karşılık 1999 yılında eğitim harcamalarının GSMH'ya oranı Türkiye için \% 3,9 olduğu belirtilmiştir. 1999-2000 öğretim yılında yükseköğretimde toplam öğretim elemanı sayısının 64.901'olduğu, lisans düzeyinde bir öğretim üyesi başına 32 öğrenciye karşılık, AB ülkeleri ortalamasının 15 ögrenci olduğu belirtilmiştir (ABGS, 2006). Bunun dışında; 
Mesleki ve teknik ortaöğretimin yeniden yapılandırılması ihtiyacına değinilerek çalışmaların başlatıldığı belirtilmiştir.

Yükseköğretimi $\mathrm{AB}$ ülkeleri ile uyumlu hale getirmek üzere başlatılan çalışmaların sürdürüleceği belirtilmiştir.

İstihdam ve eğitim ilişkisi çerçevesinde İŞKUR tarafından sürdürülen çalışmalar ile meslek standartları ve sertifikasyon sisteminin yaygınlaştırılması hedefleri programda yer almıştır.

Eğitim ve Gençlik bölümünde $A B$ 'ye uyum sağlamak üzere gerekli yapısal değişiklikler Ulusal Program'da sıralanmış, hangi yasalarda düzenleme yapılacağı belirtilmiştir.

\section{Avrupa Birliği İlerleme Raporlarında Eğitim ve Türkiye}

Haziran 1998'de yapılan Cardiff AB Konseyi toplantısında, yeni aday ülkelerin katılım sürecinde kaydettiği ilerlemeleri 1998 yılından itibaren sunması Komisyon tarafından benimsenmiștir. Türkiye'nin topluluğa katılım yönünde ilerlemesine ilişkin ilk düzenli rapor 1998 yılında sunulmuştur; 2000 yılından itibaren sunulan raporlar ise ilerleme raporları olarak adlandırılmıştır.

\section{1. 1998 Düzenli Raporunda Eğitim:}

Öğrenim, eğitim ve gençlik başlığı altında "Türkiye'de 12 milyondan fazla ilk ve orta okul öğrencisi ve 500000 kadar öğretmen vardır. 72 üniversitede toplam 1,3 milyon öğrenci yüksek tahsil yapmaktadır. Ağustos 1997'de çıkarılan bir yasa, zorunlu eğitim süresini beş yıldan sekiz yıla çıkarmış ve böylece ilk öğrenimdeki öğrenci sayısını büyük ölçüde artırmıştır" denmektedir (AB Türkiye Delegasyonu, 2006).

Raporda ayrıca; genel eğitim düzeyinin AB standartlarına yükseltmek için okul derslik sayılarında, ögretim kadrosunda ve genel olarak personel sayı ve niteliklerinde eksiklerin olduğuna yer verilmiştir.

Raporda, AB programlarına katılmaya gösterilen ilgi ve isteği; "Türkiye'nin 2000-2004 yıllarında Sokrates, Leonardo ve Avrupa İçin Gençlik Programlarına katılma imkanını öngörmektedir. Bu katılım, kültürlerin ve zihniyetlerin birbirine yaklaşmasına hizmet edecektir. Bu amaçla, uygun finansmana ek olarak, Türkiye'nin programlara katılan kişilerin serbest dolaşımını sağlaması gerekli olacaktır" şeklinde göstermektedir (AB Türkiye Delegasyonu, 2006). 


\section{2. 1999 Düzenli Raporunda Eğitim:}

Öğretim, eğitim ve gençlik başlı̆̆ı altında; "Eldeki bilgiler, bu alanda kaydedilen ilerlemeye ilişkin bir değerlendirme yapılmasına imkan vermemektedir. Komisyon ve Türk makamları, halen, Leonardo da Vinci II, Socrates II ve Avrupa İçin Gençlik başlıklı Topluluk programlarına Türkiye'nin gelecekte katılmasına imkan vermek üzere Türkiye'de uygulamaya konulacak hazırlayıcı düzenlemeleri görüşmektedir. $\mathrm{Bu}$ düzenlemeler için $\mathrm{AB}$ finansmanı öngörülmektedir" denmektedir (AB Türkiye Delegasyonu, 2006).

\section{3. 2000 Yılı İlerleme Raporunda Eğitim:}

2000 Yılı İlerleme Raporunda ülkemizin öğrenim, eğitim ve gençlik programlarına katılabilmesi için daha fazla çaba içine girdiği ve bunu desteklemek amacıyla Birliğin Türkiye'deki eğitim programlarına toplam 175 milyon Euro yardımda bulunduğu belirtilmektedir.

Zorunlu eğitim süresinin sekiz yıla çıkarılmasının önemine değinilerek bu gelişmenin ortaöğretim ve yükseköğretimde de sağlanacağ sayısının artırılacağı belirtilmektedir. 8. Beş Yıllık Kalkınma Planı'nda 2005 yılına kadar ortaöğretim de okullaşma oranlarının \% 75'e yükseltilmesi hedefine dikkat çekilmiştir.

Ayrıca, mesleki eğitime daha çok önem verilmesi ve insan kaynaklarına yatırım yapma işinin sadece kamunun görevi olmadığı vurgulanmıştır.

\section{4. 2001 Yılı İlerleme Raporunda Eğitim:}

Eğitim ve öğretim alanında sınırlı bir gelişme sağlandığı, Türkiye'nin Topluluk programlarına (Sokrates, Leonardo da Vinci ve Avrupa Gençliği) katılımı için çalışmaların yeni bir ivme kazandığı, 2003 yılından itibaren programlara katılımın başlayacağı açıklanmıştır. Topluluk programlarını yürütmek üzere Ulusal Ajans'ın nasıl kurulacağı konusunun açıklığa kavuşturulması istenmiştir.

Eğitim sistemi reformu kapsamında Türkiye Haziran 2001'de ortaöğretimdeki kaynakların 2010 yılına kadar uzatılmasıyla ilgili kanunu kabul etmiştir. Bu katkı hükümetin 8 inci Beş Yıllık Kalkınma Planı doğrultusunda 12 yıllık zorunlu öğretime 2005 yılına kadar ulaşılmasını sağlayacaktır. 
Raporda, 4702 sayılı Kanun'un, Türkiye'deki mesleki eğitim ve öğretimin yapısını etkileyerek, eğitim sisteminde yatay ve dikey geçişleri kolaylaştıran tek bir mesleki eğitim sisteminin oluşturulmasını sağlayacağı belirtilmiştir. Bu kanunla mesleki eğitim öğretim kurumlarına sınavsız giriş olanağı sağlanacağı ve mevcut sistemdeki mesleki eğitime devam edenlerin ders yüklerinin azaltılacağ 1 ifade edilmektedir.

\section{5. 2002 İlerleme Raporunda Eğitim:}

2002 İlerleme Raporu ön bilgisinde şöyle denilmektedir: Türkiye'nin son bir yılda gerçekleştirmiş olduğu siyasi reformların Kopenhag Katılım ölçütlerinin karşılanması yönünde temel bir adım oluş̧urduğunun Komisyon tarafından hazırlanan metinlerin çeşitli yerlerinde vurgulanmış olması yapıcı bir öğe olarak dikkat çekmektedir (AB Türkiye Delegasyonu, 2006).

Buna karşılık, Türkiye'nin siyasi ölçütleri tam olarak karşılamadığı, uygulamada eksiklikler bulunduğu ve her alanda daha fazla ilerleme kaydetmesi gerektiği de belirtilmektedir. Komisyon'un eleştirilerine ilişkin olarak belirtilebilecek husus, bunların bir kısmının eksik bilgiden kaynaklandığı yönündedir. İleri sürülen diğer eleştirilerin ise, dinamik bir nitelik taşıyan üyelik süreci bağlamında ortaya konmuş bulunan siyasi irade doğrultusunda hızla giderilmekte olduğu belirtilmiştir. Ulusal Ajansın kurularak çalışmaya başlaması olumlu bir gelişme olarak kabul edilmiştir.

\section{6. 2003 Yılı İlerleme Raporunda Eğitim:}

Türkiye'nin ilgili Topluluk programlarına katılımından sorumlu birimin Ocak 2002'de Devlet Planlama Teşkilatı bünyesinde kurulmasını takiben, 32 yeni personel atanma ve farklı bakanlıklardan görevlendirme suretiyle istihdam edilmiştir. Söz konusu birim, gelecekte Sokrates, Leonardo da Vinci ve Gençlik Programlarından sorumlu olacak olan Ulusal Ajans olarak faaliyet göstermektedir. Bu birim, Komisyon ile işbirliği halinde çalışma planları oluşturmuş ve hazırlık tedbirlerinin tümünü uygulamaya koymuştur. Söz konusu birimin Türk Ulusal Ajansı olarak faaliyet göstermesini teminen hukuki statüsünü ve idari ve mali özerkliğini düzenlemek amaciyla, Temmuz 2003'de Devlet Planlama Teşkilatı Kuruluş ve Görevleri Hakkında Kanun Hükmünde Kararnamede değişiklik yapılmıştır.

Göçmen işçi çocuklarının eğitimine ilişkin direktifin iç hukuka aktarılması amacıyla, Kasım 2002'de bir kanun kabul edilmiştir.

Bir önceki hükümet, eğitim ve mesleki eğitim sistemine ilişkin olarak, zorunlu eğitim süresini 2005 yılına kadar 8 yıldan 12 yıla çıkarmaya ve orta öğretim süresini 2002-2003 Öğretim yılına kadar 3 yıldan 4 yıla çıkarmaya yönelik tedbirleri uygulamaya başlamışt. Kasım 2002'de seçilen yeni 
hükümet de, zorunlu eğitim süresini 2005 yılına kadar 12 yıla çıkarmaya isteklidir fakat, orta öğretim süresini 4 yıla çıkarmayı hedefleyen tedbirleri kaldırmıştır. Hükümet, mesleki okulları daha çekici kılmak ve yoksul ailelerin çocuklarının okullaşma oranını yükseltmek hususunda çaba sarf etmektedir.

Son rapordan bu yana, Türkiye'de, engelli çocukların okul öncesi zorunlu eğitimini geliştirme yönünde ilerleme sağlanmamıştır.

Yükseköğretimde, Yüksek Öğretim Kanunu'na tabi eğitim sisteminin oldukça merkeziyetçi olduğu belirtilmektedir. Raporda; "Yüksek Öğretim Kanununda yer alan temel ilkeler ile eğitim programları arasındaki uyumun denetiminden sorumlu olan ve rektörler ve fakültelerle ilgili olarak geniş disiplin yetkileri kullanan güçlü bir Yüksek Öğretim Kurumunun (YÖK] varlığı nedeniyle, yükseköğretim sisteminde, akademik, idari ve mali özerklik eksikliği bulunmaktadır" denmektedir (AB Türkiye Delegasyonu, 2006).

Raporda, TBMM'nin her yıl Yüksek Öğretim Kurumu'nun bütçesini kabul etmekte olduğu, ancak söz konusu Kurumun harcamalarını denetleyemediği belirtilerek; "Milli Eğitim Bakanı TBMM'de yüksek ögretim sistemini temsil etmekte ve YÖK toplantılarına başkanlık edebilmektedir, fakat oy hakkı bulunmamaktadır. Ayrıca ne YÖK kararları ne de üniversite kararları Bakanlık onayına tabi değildir. Milli Güvenlik Kurulu da Yüksek Öğretim Kurulunda temsil edilmektedir. Bu yap1, üniversitelerin istihdam piyasasına daha fazla yönelmelerine engel olmaktadır. Üniversite mezunları arasındaki yüksek işsizlik oranı bu görüşü desteklemektedir. Üniversiteleri, arz yönlü yapıdan, istihdam piyasasından kaynaklanan talep üzerine kurulu bir yapıya kavuşulmak amaciyla eğitim sisteminde reform yapılması gerekmektedir" şeklinde görüş bildirilmiştir. (AB Türkiye Delegasyonu, 2006).

1997'de çıartılan bir kanun, engelli çocuklar için okul öncesi zorunlu eğitimi öngörmekle birlikte, Türkiye'nin bu yöndeki kapasitesi yetersizdir 2002-2003 Öğretim yılında okul öncesi eğitime sadece 61 engelli çocuk devam etmiştir.

Milli Eğitim Bakanlığı, fakir ailelerin, çocuklarını okula göndermelerini sağlamak amacıyla, 2003-2004 Öğretim yılında, temel eğitimde okul kitaplarının ücretsiz dağıtılmasına karar vermiş̧tir. Bu önemli tedbirin özellikle kızların okula gitme oranını yükseltmesi beklenmektedir. 
Sekizinci Beş Yıllık Kalkınma Planı, orta öğretimde okullaşma oranının artırılmasında başarılı olmakla birlikte, genel liselere devam oranının azaltılarak mesleki ve teknik eğitim okullarına yönelimi sağlama konusunda başarılı olamamıştır.

Genel olarak orta öğretimde iki temel sorun varlığını sürdürmektedir. Öncelikle, orta öğretime olan talep öngörülenden çok daha yüksektir, ikinci olarak, mesleki ve teknik okullara yönlendirilen öğrenci sayısı planlanandan daha azdır. Üniversiteye giriş sınavları genel liselerden mezun öğrenciler lehine bir ayrıma yol açmaktadır.

Türkiye, 1970'lerden bu yana orta öğretimde mesleki ve teknik eğitimi öne çıkaran planlar uygulamaktadır. Orta öğretim sonrası meslek yüksek okullarına sınavsız giriş hakkı dahil, mesleki ve teknik orta öğretimin konumunu güçlendirmeye yönelik birçok yasal tedbir alınmakla birlikte, söz konusu tedbirler düz liselere olan eğilimi tersine çevirmemiştir. Sonuç olarak, eğitim ve mesleki eğitim alanında bazı ilerlemeler kaydedilmiştir. Türkiye, üç Topluluk programına katılıma yönelik hazırlıklarını sürdürmeli ve tamamlamalıdır. Göçmen iş̧̧i çocuklarının eğitimine yönelik olarak vilayetlerce alınan tedbirler izlenmelidir. Üniversiteleri istihdam piyasasına daha fazla yönlendirmek amacıyla YÖK'ün koordinasyon görevi gözden geçirilmelidir. Türkiye, Özel eğitime muhtaç çocukların erken teşhis edilmesine yönelik gerekli tedbirleri almalı ve söz konusu çocuklar için okul öncesi eğitim imkanlarının sağlanmasına özen göstermelidir. Türkiye, orta öğretime yönelik olarak planlanan hedef ve stratejilerini gözden geçirme ve orta öğretimin yüksek öğretim üzerindeki baskısını hafifletme yönünde teşvik edilmelidir.

\section{7. 2004 İlerleme Raporunda Eğitim:}

06 Ekim 2004 de yayımlanan İlerleme Raporu'nun 29 başlıktan biri olan ve 18 nolu Genel ve Mesleki Eğitim başlığı altında verilmiş olan bölüm özet olarak değerlendirildiğinde sonuçlar iki bölümde ele alınabilir: Birinci bölümde eğitimle ilgili olumlu gelişmeler, ikinci bölümde ise henüz yerine getirilmesi gereken eksik ve olumsuzluklar içeren bölüm yer almaktadır.

\subsubsection{Raporda Olumlu Gelişmeler:}

Topluluk Eğitim programlarına (Socrates, Leonardo ve Youth) katılım sürecinde büyük ölçüde 'ilerleme sağlanmıştır. Programların koordinasyonunu sağlayan Ulusal Ajansın uygulama kapasitesi, hem personel hem de altyapı açılarından güçlendirilmiştir.

Göçmen çocuklarının eğitimine ilişkin kanun yürürlüğe konmuştur. 
Eğitimi desteklemek için yeni okul yaptıran ya da mevcut okulların tefrişi için kaynak aktaran özel şahıslara vergi muafiyetleri sağlayan mevzuat sayesinde 277 yeni okul yaptırılmış ve 200 okul tadilattan geçmiştir.

Çocukların okula devam oranlarını artırabilmek amacıyla, 2003/2004 yılında ilköğretim kitapları ücretsiz olarak dağıtılmış ve olumlu etki yapmıştır.

Anayasada Mayıs 2004'te yapılan bir değişiklikle, YÖK'e Genel Kurmay Başkanlığından bir üye atanması uygulaması kaldırılmıştır.

\subsubsection{Yerine getirilmesi gereken eksikler ve olumsuzluklar:}

Topluluk programlarının koordinasyonunun ve yönetiminin daha da iyileştirilmesi için çabaların devam etmesi gerekmektedir. Türkiye'de eğitime aktarılan kaynak, GSYİH oranı açısından AB ortalamasının altındadır.

Okulu erken terk oranları oldukça yüksektir. İlerleme kaydedilmiş olmakla birlikte, kız ve erkek çocukların eğitimleri arasında farklılıklar bulunmaktadır. Özürlü çocukların da okula gidebilmeleri için çabalar artırılmalıdır.

YÖK'ün geniş disiplin yetkileri bakımından yüksek öğrenimde oluşan merkezi yap1 yüzünden üniversiteler akademik, idari ve mali özerkliğe yeterince sahip değillerdir ve iş gücü piyasalarına yeterince odaklanamamaktadırlar. Bu nedenle YÖK'ün koordinasyon görevi tekrar gözden geçirilmelidir.

Öğrencilerin mesleki okullardan üniversitelere geçişi zorlaştı̆̆ ölçüde, bu okullara başvurularda düşüş gözlenmektedir. Mesleki eğitim politikalarının belirlenmesinde sosyal ortakların katılımı yetersiz kalmaktadır (Milli Eğitim Bakanlığı, 2007).

\section{8. 2005 İlerleme Raporunda Eğitim}

Raporda, 26. fasıl Eğitim ve Kültür başlığı altında, öğrenim, eğitim, gençlik ve kültür alanlarının genel olarák üye ülkelerin yetkisinde olduğu belirtilerek ulusal politikaların uyumlu hale getirilmesi, eşgüdüm sağlanması ve paylaşılan hedeflere ulaşılmasının, Avrupa düzeyinde eğitim ve öğretim alanlarında bütün faaliyetleri bütünleştiren 'Eğitim ve Öğretim $2010^{\prime}$ programının geliştirildiği belirtilmiştir. Kültürel çeşitlilik konusunda 
ise üye ülkelerin, AT Antlaşmasının 151. maddesinde yerini bulan ilkelere uymaları ve uluslararası yükümlülüklerinin kültürel çeşitliliğin korunması ve ilerlemesine imkan vermesini sağlamaları; eğitim, Topluluk programlarının (Leonardo da Vinci, Socrates, Youth) mali yönetiminin sağlıklı bir şekilde sağlanması için üye ülkelerin hukuki, idari, mali çerçevelere ve gerekli uygulama kapasitesine sahip olmalan gerektiği belirtilmiştir (European Commission, 2006).

Eğitim ve ögretim alanında Türkiye, Nisan 2004 ayından bu yana Topluluğun Leonardo da Vinci, Socrates, Youth programlarına son derece başarılı bir şekilde katılmaktadır. Türk Ulusal Ajansı tarafından yürütülen bilgilendirme kampanyalarının da desteğiyle, bu programlar öğrenciler ve genç profesyoneller arasında büyük ilgi görmüştür. 2004 yılında zaten önemli bir şekilde artış kaydeden başvuru sayısı 2005 yılında daha da yükselmiştir (AB Türkiye Delegasyonu, 2006).

Türk Ulusal Ajansı, projelerle ilgili seçim, sözleşme, menfaat sahiplerine ödeme, proje denetleme ve Komisyona bilgi verme dahil, programların dağıtılmış faaliyetlerin yönetimine ilişkin görevlerini tatminkar bir şekilde yerine getirmiştir. Türk Ulusal Ajansı, AB ortaklarıyla birlikte 9000'den fazla Türk katılımcının dahil olduğu projeler için bu faaliyetlere tahsis edilen fonların \% 90'ının ihalesini gerçekleştirebilmiştir. Türk Ulusal Ajansının, başvuru sayılarındaki önemli artışla baş edebilmek için yönetim kapasitesini takviye etmeye yönelik çabalarını sürdürmesi gerekmektedir (AB Türkiye Delegasyonu, 2006).

Devlet Planlama Teşkilatı, Milli Eğitim Bakanlığı, AB İşleri Genel Sekreterliği, Yüksek Öğretim Kurulu, Gençlik ve Spor Genel Müdürlüğü ve Türk İş Kurumu temsilcilerinde oluşan bir Yönetim ve İzleme Komitesi, Birlik Programlarının uygulanmasına yönelik genel politikalar belirlemek ve Ulusal Ajansın çalışmasını izlemekte ve değerlendirmek için düzenli toplantılar yapmaktadır. Programları, bu alandaki ulusal politikalara da faydalı olmasını sağlamak için, sektörel bakanlıkların Yönetim ve İzleme Komitesine etkin katılmaları gereklidir. $\mathrm{Bu}$ bağlamda, ilgili bütün bakanlıklar arasında işbirliği ve eşgüdüm güçlendirilmelidir ( $A B$ Türkiye Delegasyonu, 2006).

Türkiye, AB Lizbon stratejisinin, bir parçası olan Eğitim ve Öğretim 2010 çalışma programına katılmaktadır.' Milli Eğitim Bakanlığı, 2010 çalışma programının uygulanışı hakkındaki 2006 Ortak Raporu'na katkı olarak, Türkiye'nin eğitim ve öğretim sistemlerinin modernizasyonu hakkında bir ulusal rapor sunmuştur. 
Eğitime erişimde gelişme olmuştur. Son dört yılda, okul öncesi eğitimdeki çocuk sayısındaki \% 68'lik bir artış halen düşüktür (bu yaş grubunun \% 16's1). 2003 yılında başlatılan ve kız çocukların okula gönderilmesini teşvik eden kampanya, 2005 yılında 20 şehirde daha uygulamaya sokulmuştur ve bu alandaki çabalar sürdürülmektedir. Özel eğitime tabi çocukların eğitimi için daha çok mali kaynak tahsis edilmiş olmakla birlikte, hala bu alanda yapılacak çok şey vardır.

2005 - 2006'da Ulasal çapta uygulanması öngörülen, temel eğitimin ilk beş sınıfının yeni ders programının pilot uygulaması, 2004 - 2005 'te 9 şehirde 120 ilköğretim okulunda başlamıştır. 6'dan 8'e kadar olan sınıfların ders programları kabul edilmiştir.

Mesleki ve teknik eğitimin güçlendirilmesine ilişkin, Eğitim Kurulu hem genel hem meslek liselerinin üç yıldan dörde çıkarılması uygulamasına başlamıştır. Bu reform, mesleki / teknik ve genel ortaokullar arasında yatay geçişi sağlamıştır. Bunun tersine, teknik lise mezunlarının üniversite giriş sınavindaki katsayısı düşürülmüştür.

Öncelik, işletmelerde ve meslek örgütlerinde beceri eğitiminin geliştirilmesine verilmelidir. Mesleki ve teknik eğitim (MTE) için öğretmen yetiştiren Mesleki ve Teknik Eğitim Fakülteleri, Avrupa Kredi Transfer Sisteminin uygulanabilmesi için yeniden yapılandırılmalıdır. Bu, Yüksek Öğretim Kurulu (YÖK) ve Milli Eğitim Bakanllğı ile işbirliği içerisinde ve halihazırda devam eden MTE Modernizasyon programından yararlanarak, tüm yüksek öğretim sisteminin yeniden yapılandırılmasının bir parçası olarak ele alınmalıdır.

Yüksek öğretim alanında, Bologna sürecinin Türkiye'de uygulanmasında kayda değer ilerlemeler sağlanmıştır. Akademik değerlendirme ve kalite kontrol alanındaki mevzuat, Kalite Teminatı için Avrupa Ağı tarafından geliştirilen Avrupa standartları ve yönergeleri dikkate alınarak gözden geçirilmiştir. Ulusal bir diploma eki, Avrupa Komisyonu, Avrupa Konseyi ve UNESCO tarafından ortaklaşa olarak hazırlanan bir model temel alınarak hazırlanmış ve Türk üniversitelerine dağıtılmıştır; uygulanması Türkiye'deki tüm yüksek öğretim kurumlarında 2005 yılından itibaren zorunlu olacaktır (AB Türkiye Delegasyonu, 2006). 
Kültürle ilgili olarak, Türkiye Temmuz ayında Külttür 2000 programına katılma isteğini teyit etmiş ve 2006'daki katılımı için gerekli olan mali katkısını ödemeye hazır olduğunu beyan etmiştir.

\section{9. 2006 İlerleme Raporunda Eğitim}

Raporda, 26. fasıl Eğitim ve Kültür başlığı altında, eğitim, öğretim ve gençlik konularında iyi gelişme kaydedildiği belirtilmiştir. Türkiye, Topluluğun Leonardo da Vinci, Socrates ve Youth programlarında başarılı biçimde katılmış ve programların ülke genelinde tanıtılmasına yönelik önlemler alınmıştır. Programlara başvurularda kayda değer artış vardır. Türkiye'nin Lifelong Learning ve Youth in Action programlarına katılma isteği dikkate alındığında, Ulusal Ajans'ın güçlendirilmesi ve katılım koşullarının azaltılması yararı olacaktır. Türkiye, Eğitim ve Öğretim 2010 Çalışma Programı Eşgüdümü Grubuna ve çeşitli kümelere aktif bir şekilde katılmaya başlamıştır. OECD ortalamasının altında kalmalarına rağmen, tüm eğitim düzeylerinde okullaşma oranlarında artış görülmüştür. Kamuoyuna etkin biçimde duyurulmuş olan kız çocuklarının eğitimine yönelik kampanya başarılı olmuştur. İlköğretim ve mesleki eğitimde gözden geçirilmiş yeni programlar uygulamaya konulmuştur. Yaşamboyu eğitime katılım oranları çok düşüktür, ancak 2000 yılında \% 1.1 oranına kıyasla 2005 'te \% 2'ye yükselmiştir. Avrupa Kredi Transfer Sisteminin Haziran'da Türkiye'de zorunlu olması ile birlikte yüksek ögretimde Bologna sürecinin uygulaması yönündeki gelişme devam etmiştir (European Commission, 2006).

Türkiye, Culture 2000 isimli Topluluk programında yer almaya başlamış̧ır. Türkiye, Ceşitlilik ve Kültürel Farklılığın Korunması ve Geliştirilmesine İlişkin UNESCO Sözleşmesi'nin kabulünü desteklemiş ve onay için iç işlemler başlamıștır. İstanbul 2010'da Avrupa Kültür Başkenti olmak için başvuruda bulunmuştur (AB Türkiye Delegasyonu, 2006).

\section{Sonuç ve Değerlendirme}

Türkiye, AB adaylık statüsünün kabul edildiği 1999 tarihinden itibaren kaydettiği gelişimi toplam 33 başlık altında (Türkiye Ulusal Programı, 2000) her yılın sonunda hazırlanan bir ilerleme raporu ile izleyebilmektedir. Bu başlıklardan biri olan 'eğitim”, sıra ve isim değişikliğine uğrayarak 'Eğitim ve Kültür' başlığıyla incelenmektedir.

Ulusal Program'la üstlenilen eğitim konularındaki gelişmeler her bir ilerleme raporunda ayrı ayrı yer almıștır. Ulusal Program ve ilerlenme raporlarında eğitim konusundaki ilerlemeler tablo I'de özet olarak
verilmiştir. 
Tablo 1: Ulusal Programda 'Eğitim, Staj ve Gençlik' Başlığında Hedefler, Yapılması Planlanan Değişiklikler ve İlerleme Raporlarında Durum Tablosu

\begin{tabular}{|c|c|c|c|}
\hline Konu & Hedef ve beklentiler & Sonuç & $\begin{array}{c}\text { Sorumlu } \\
\text { Kuruluş/lar }\end{array}$ \\
\hline 3797 Sayılı Kanun & $\begin{array}{l}\text { Yetki ve sorumluluk } \\
\text { devri }\end{array}$ & Yapılmamıştır & MEB \\
\hline 3308 Sayılı Kanun & $\begin{array}{l}\text { Mesleki ve Teknik } \\
\text { Eğitim ile Sanayi } \\
\text { işbirliği }\end{array}$ & $\begin{array}{l}4702 \text { Sayılı Kanun } \\
\text { kabul edilmiş, } \\
\text { yönetmelikler } \\
\text { tamamlanmamıştır }\end{array}$ & MEB-ÇSGB \\
\hline $\begin{array}{l}\text { Ulusal Meslek } \\
\text { Standartlan Kanunu }\end{array}$ & $\begin{array}{l}\text { Meslek standartlan } \\
\text { geliștirilmesi }\end{array}$ & Tamamlanmamıştır & ÇSGB \\
\hline $\begin{array}{l}\text { Zorunlu eğitimin 9-12 } \\
\text { yıla çıarılması }\end{array}$ & $\begin{array}{l}\text { AB ülkeleri } \\
\text { ortalamasına uyum } \\
\text { sağlama }\end{array}$ & Yapılmamıştır & MEB \\
\hline $\begin{array}{l}\text { Ulusal Ajans'in } \\
\text { kurulması }\end{array}$ & $\begin{array}{l}\text { AB programlarına } \\
\text { katılım }\end{array}$ & Kurulmuştur & DPT \\
\hline $\begin{array}{l}\text { Meslek Yüksek } \\
\text { Okullanı }\end{array}$ & $\begin{array}{l}\text { Öğretim elemanı, } \\
\text { fiziksel alt yapıda } \\
\text { iyileștirme ve denklik }\end{array}$ & Tamamlanmamıştır & MEB, YÖK \\
\hline Yetişkin eğitimi & $\begin{array}{l}\text { Eğitimin tüm } \\
\text { boyutlarında } \\
\text { yaygınlaștırma }\end{array}$ & Gelişmeler vardır & MEB, TESK \\
\hline $\begin{array}{l}\text { Yükseköğretimin } \\
\text { yeniden yapılanması }\end{array}$ & $\begin{array}{l}\text { Yükseköğretim } \\
\text { kurumlannın daha } \\
\text { özerk yapıya } \\
\text { kavușturulması }\end{array}$ & Yapılmamıştır & MEB, YÖK, \\
\hline $\begin{array}{l}\text { Orta ögretimin } \\
\text { yeniden } \\
\text { yapılandırılması }\end{array}$ & $\begin{array}{l}\text { Mesleki ve Teknik } \\
\text { Eğitimin } \\
\text { güçlendirilmesi }\end{array}$ & Yapılmamıştır & MEB \\
\hline $\begin{array}{l}\text { Göçmen işçi } \\
\text { çocuklannın eğitimi }\end{array}$ & $\begin{array}{l}\text { Göçmen işçi } \\
\text { çocuklarının eğitimden } \\
\text { yararlanmaları }\end{array}$ & Kanun çıkmıştır & MEB \\
\hline $\begin{array}{l}\text { Bütçeden Eğitime } \\
\text { ayrilan payın } \\
\text { artırnlması }\end{array}$ & $\begin{array}{l}\text { Eğitime yatırımların } \\
\text { artırılması }\end{array}$ & Yapılamamıştır & MEB, DPT, MB \\
\hline $\begin{array}{l}\text { Okul öncesi eğitimde } \\
\text { okullaşma oranlanının } \\
\text { artırnlması }\end{array}$ & $\begin{array}{l}\text { Uzun vadede zorunlu } \\
\text { eğitimin okul } \\
\text { öncesinden başlatılması' }\end{array}$ & $\begin{array}{l}\text { \%16 düzeyinde } \\
\text { kalmıştır }\end{array}$ & MEB \\
\hline $\begin{array}{l}\text { Özel eğitime muhtaç } \\
\text { çocuklann eğitimi }\end{array}$ & $\begin{array}{l}\text { Özel eğitime önem } \\
\text { verilmesi }\end{array}$ & Gelişme vardır & MEB \\
\hline $\begin{array}{l}\text { Yeni ilköğretim ders } \\
\text { programlarının } \\
\text { uygulanması }\end{array}$ & $\begin{array}{l}\text { Yapılandırıcı ve ögrenci } \\
\text { merkezli eğitim } \\
\text { uygulaması }\end{array}$ & Tamamlanmıştır & MEB \\
\hline
\end{tabular}


Tabloda olabildiğince sınırlandırılarak verilen konu başlıkları, hedef ve beklentiler, ulaşılan sonuçlar ve sorumlu kuruluşlar belirtilmiştir. Buna göre;

1. 3797 sayılı Milli Eğitim Bakanlığı Teşkilat ve Görevleri Hakkındaki Kanun'da beklenen değişikler yapılamamıştır. Milli Eğitim Bakanlığı'nın merkeziyetçi ve hantal yapısı devam etmektedir.

2. 4702 say1lı Mesleki Eğitim Kanunu kabul edilmiş, ancak uygulama yönetmelikleri çıkarılamadığ için uygulamaya yönelik değişiklikler yapılamamıştır. Mesleki eğitim politikalarının belirlenmesinde sosyal ortakların katılımı yetersiz kalmıştır.

3. Zorunlu eğitimin 9-12 yıla çıkarılması hedefi gerçekleştirilememiştir. Henüz sekiz yıllık zorunlu eğitimde okullaşma oranlarındaki düşüklük ile eğitimde bölgesel farklılıklar devam etmektedir. Okullaşma oranları açısından kız ve erkek çocukların eğitimleri arasında önemli farklılıklar vardır. Özürlü çocukların da okula gidebilmeleri için çabalar yetersiz kalmıştır.

4. Yükseköğretimin yeniden yapılandırılması yanlış politikalar nedeniyle sonuçsuz kalmıştır. Yükseköğretimde asıl ihtiyaç göz ardı edilerek mevcut yapının korunmasına olanak verilmiştir. YÖK'ün koordinasyon görevi tekrar gözden geçirilmelidir.

5. Ortaögretimde yeniden yapılanma kapsamında mesleki ve teknik eğitme gerekli önem verilememiş, ögrencilerin ilgi ve yeteneklerine uygun alanlara yönlendirilmesi ve mesleki ve teknik eğitimin güçlendirilmesi sağlanamamış, sınavla yöneltme daha da ağırlık kazanmıştır.

6. Eğitime verilen önem, eğitime ayrılan kaynaklarla doğru orantılıdır, ancak bütçeden eğitime ayrılan paylar henüz $\mathrm{AB}$ ortalamalarının çok altındadır.

Türk Eğitim Sistemi'nin yeniden yapılanması başta olmak üzere eğitimde kalitenin artırılması, eğitime erişim ve yaygınlaştırma, üst ögretime yönlendirme ve mesleki eğitim, genel bütçeden eğitime ayrılan kaynakların sınırlılığı ve yükseköğretimin yeniden yapılandırılması konusunda ilerleme kaydedilememiştir. Türkiye'nin Avrupa Birliği'ne adaylık sürecinde serbest dolaşım, istihdam ve mesleki standartların sorun teşkil etmemesi için eğitim sisteminin hıla ihtiyaç duyulan iş gücünü yetiştirme kapasitesine ulaşabilmesi gereklidir. 
Genç bir nüfusa sahip olan Türkiye için bu genç nüfus, işsizlik açısından bakıldığında dezavantaj, dinamik iş gücü açısından ise avantaj olarak görülebilir. Avrupa Birliği ülkelerinin gelecekte ihtiyaç duyacağı iş gücünü sağlamak Türkiye için önemli bir kazanım sayılabilir. Bunu sağlayabilmek için özellikle mesleki eğitimin $\mathrm{AB}$ ülkelerine uyumlu hale getirilmesi gereklidir. Diğer taraftan, yüksek öğretime olan talebin artarak devam etmesi karşısında plansız bir yeni üniversite açma politikaları da Türkiye'nin AB ye uyumunu kolaylaştırmaktan çok zorlaştırdığını göstermektedir. Çünkü, yüksek öğretimde kalitenin azalması $\mathrm{AB}$ ülkeleri yüksek ögretimi ile denklik sorunlarının artması anlamına gelecektir.

Sonuç olarak adaylık bir bütün olarak değerlendirildiğinde, eğitim konusunda atılması gereken henüz pek çok adım vardır. Eğitim ve kültür konularının ülkelerin tercihlerine bırakılmış olmasına bakılmaksızın Ulusal Program'da yer alan taahhütlerin yerine getirilmesi için Milli Eğitim Bakanlığı, üniversiteler, sivil toplum kuruluşları, meslek kuruluşları ve sanayi kuruluşları ile iş birliğini geliştirerek sürdürmelidir.

\section{Kaynakça:}

2004 Yılı İlerleme Raporunun Ekonomik Kriterler ve AB Müktesebatına Uyum Bölümlerinin Değerlendirmesi (2004). Avrupa Birliği Genel Sekreterliği.Erişim: Kasım 2004, http://www.meb.gov.tr/duyurular/duyurular/AvrupaKomisyonu/ilerleme Raporu2004.htm

A New Idea For Europa (2000). European Commission.

AB Türkiye Delegasyonu (2006). Erişim: 27 Kasım 2006, http://www.deltur.cec.eu.int.

Avrupa Birliği Genel Sekreterliği (2006). Avrupa Birliği. Erişim: 27 Kasim2006, http://www.abgs.gov.tr/indextr..php?p=3\&l=1

Avrupa Birliği Müktesebatının Üstlenilmesine İlişkin Türkiye Ulusal Programı (2001). Avrupa Birliği Genel Sekreterliği. Ankara.

Avrupa Birliği Üye Ülkeleri Eğitim Politikaları (1996). Milli Eğitim Bakanlığı.

Baydarol, Can. (2000). Avrupa Birliğinin Genişlemesi. Ankara: Avrupa 
Komisyonu Türkiye Temsilciliği.

Compendium 2004 (2005). European Commission.

Data on Education in Europe (2002). European Commission (Ed. And Culture)

European Commission (2006). Enlargement Strategy and Progress Reports 2006. Erişim: 27 Kasım 2006, http://ec.europa.eu/enlargement/key_docu ments/reports_nov_2006 en.htm

Europäische Konvent. Erişim: 27 Kasım 2006, http://europeanconvention.eu.int

Eurydice (2006). Erişim: 27 Kasım 2006, http://www.eurydice.org/portal/page/portal/Eurydice

Gülcan, M. (2005). AB ve Eğitim Süreci. Ankara: Anı Yayıncılık.

Milli Eğitim Politikaları ve Şuralar (1996). Talim ve Terbiye Kurulu. Ankara.

Milli Eğitim Bakanlığı (2007). Avrupa Birliği İlerleme Raporları. Erişim: 27 Kasim 2007, http://www.meb.gov.tr.

ODTÜ AB Ofisi (2006). Avrupa Birliği Politikaları. Erişim: 27 Kasım 2006, http://www.abofisi.metu.edu.tr/ab_uzerine.htm

Sayılarla Türkiye ve Avrupa Birliği 1991-1996. (1996). Devlet Ístatistik Enstitüsü.

Sekizinci Beş Yıllık Kalkınma Planı (2001). Devlet Planlama Teşkilatı. Ankara.

Türkiye Ulusal Programı (2000). Başbakanlık Devlet Planlama Teşkilatı. Ankara.

Türkiye Ulusal Programı (2001). Avrupa Birliği Genel Sekreterliği. Ankara.

T.C. Dışişleri Bakanlığı (2006). Türkiye 2007 İlerleme Raporu (6 Kasım 2006). Erişim: 27 Kasım 2006, http://www.mfa.gov.tr.

Ulusal Ajans (2006). Comenius: Program Hakkında. Erișim: 27 Kasım2006, http://www.ua.gov.tr//index.cfm?action=detay $\&$ bid $=8$ 